\title{
Relationships between the distribution of Galba truncatula (Gastropoda: Lymnaeidae) climatic conditions and the altitude of municipalities in Haute Vienne (France)
}

\author{
Gilles Dreyfuss ${ }^{*}$, Philippe Vignoles and Daniel Rondelaud \\ Laboratory of Parasitology, Faculty of Pharmacy, 2, rue du Docteur Raymond Marcland, 87025 Limoges, France
}

Received: 11 January 2018; Accepted: 6 March 2018

\begin{abstract}
A retrospective study on 7407 populations of Galba truncatula found in the department of Haute Vienne for 37 years (1970-2006) was carried out to determine if altitude and climate on acid soils had an effect on the distribution of populations and the characteristics of their habitats. Out of a total of 13478 water points surveyed in 179 municipalities, the overall frequency of snail populations was $54.9 \%$ but varied with the habitat type and the municipality on which these water points are located. The frequency of snail populations significantly decreased when the mean altitude of municipalities or their mean annual rainfall increased. Conversely, this frequency significantly increased with increasing mean annual temperature. The characteristics of habitats were analysed for 6281 populations in relation to the mean altitude of municipalities. The area of $G$. truncatula habitats and the density of overwintering snails per $\mathrm{m}^{2}$ of habitat significantly decreased with increasing altitude. On the acid soils of Haute Vienne, the distribution of $G$. truncatula populations is closely related to the altitude and climatic conditions of municipalities.
\end{abstract}

Keywords: Altitude / climate / distribution / Galba truncatula / habitat / Haute Vienne

\section{Introduction}

The snail Galba truncatula O.F. Müller (Mollusca Pulmonata: Lymnaeidae) is known as the common intermediate host of the parasite Fasciola hepatica Linnaeus (Platyhelminthes Digenea: Fasciolidae) in numerous countries of the world (Torgerson and Claxton, 1999; Mas-Coma et al., 2009). This lymnaeid has a large geographic range, including Africa, Asia, Europe and North America (Seddon et al., 2015). In South America, this snail is also present in several countries and has reportedly been introduced from Europe (Bargues et al., 2017). In France, the distribution of G. truncatula is still uncertain. According to Germain (1930/1931), the species was common throughout the country, but less widespread in southeastern France and Corsica. The presence of many empty shells found in archaeological excavations during the past decades has confirmed this distribution of $G$. truncatula in France (Limondin and Rousseau, 1991; Guitter et al., 2003; Granai et al., 2011; Magnin and Bonnet, 2014), as shown on the map published by the National Museum of Natural History in Paris (Muséum National d'Histoire Naturelle, 2003-2017). However, this appears to have changed over time. The presence of the species is currently probable or real in many

*Corresponding author: gilles.dreyfuss@unilim.fr departments, whereas its absence is probable or real in the Paris region, the Côtes d'Armor, Finistère, Ille et Vilaine, and Yonne (Muséum National d'Histoire Naturelle, 2003-2017). Knowing the distribution of the host snail in a given region therefore enables to specify the local characteristics of the disease in the definitive host and to better target the measures to be taken to control it.

The development of $G$. truncatula populations and, consequently, the transmission of $F$. hepatica are dependent on the climate in the country where lymnaeid lives. The most favourable conditions are temperatures ranging between 10 and $25^{\circ} \mathrm{C}$ and high relative humidity depending on atmospheric precipitations (Taylor, 1965). As a result, the disease is common in temperate regions like most European countries (Torgerson and Claxton, 1999). However, the existence of snail habitats also depends on geological formations and the topography of a land (Rapsch et al., 2008). These last factors enable to determine whether or not snail habitats can be present in a given area (Ollerenshaw and Smith, 1969; Ollerenshaw, 1971). Climatic factors and soil conditions were used by several authors (Malone et al., 1998; 2001; Malone and Yilma, 1999) to develop predictive models to estimate the risk caused by fasciolosis. Using different techniques including the Geographic Information System, endemic areas for fasciolosis were specified in different countries of the world like Ireland (Selemetas et al., 2015), Sweden (Novobilský et al., 2015), 
Switzerland (Rapsch et al., 2008; Baggenstos et al., 2016) or the United Kingdom (Fox et al., 2011). Most models were mainly validated by means of surveys on the prevalence of $F$. hepatica infection in the definitive host (Malone et al., 1998; Tum et al., 2007). In contrast, those using data on the intermediate host are much less numerous (Rapsch et al., 2008; Baggenstos et al., 2016).

In Central France, the populations of $G$. truncatula were quite numerous on the cristallophyllian soils of Limousin. Seven habitat types have been described in this region by Vareille-Morel et al. $(1999,2007)$. The distribution of snail habitats according to their size and abundance of overwintering snails has been refined in subsequent works (Rondelaud et al., 2011; Dreyfuss et al., 2015). However, these results concern all the stations colonized by the lymnaeid on acid soils in the three departments of Limousin (Corrèze, Creuse, Haute Vienne) and one may wonder whether there were any variations in the number and characteristics of these habitats in relation to the geographic data and climatic conditions of the department. This assumption is based on the report by Vignoles et al. (2017). According to these authors, the prevalence of $F$. hepatica infection in G. truncatula significantly decreased in Haute Vienne with the increase in altitude or the decrease in the mean annual temperature of municipalities. In view of this result, the following two questions arose: did the populations of G. truncatula show variations in their number according to the relief and climate of the Limousin municipalities? Did the characteristics of their habitats also change in relation to the altitude of municipalities? To answer these two questions, a retrospective study was carried out on snails that our team collected between 1970 and 2006 in Haute-Vienne. This department was chosen for this study because of numerous samples of snails collected by our team in this area from the 1970s.

\section{Materials and methods}

\subsection{Study area}

The department is located in the north-western part of the Massif Central (Fig. 1). The latitude of this region ranges from $45^{\circ} 26^{\prime}$ to $46^{\circ} 21^{\prime} \mathrm{N}$, whereas its longitude ranges from $0^{\circ} 48^{\prime}$ to $1^{\circ} 34^{\prime} \mathrm{E}$. Its surface area is about $5520 \mathrm{~km}^{2}$. In this department, there are three larger districts: the Basse Marche (altitude, 150$300 \mathrm{~m}$ ) in the northern third, the valleys of the Vienne river and its tributaries (altitude, $150-400 \mathrm{~m}$ ) largely located in the central part, and the plateaus and mounts of Limousin (altitude, 300-777 m) along the eastern, south-eastern and south-western borders of the department (Chèvremont, 2008). The subsoil is mainly composed of granite or gneiss, with some outcrops of mica-schist or serpentinite. The result is the presence of numerous rivers $(>7000 \mathrm{~km})$. In the Basse Marche district, the $\mathrm{pH}$ of the water flowing through G. truncatula habitats ranges from 5.9 to 7.8 depending on the habitat type, with a mean value of $6.5 \pm 0.8$. When habitat altitude is increasing, the $\mathrm{pH}$ value decreases and varies from 5.6 to 6.8 in the Mounts of Ambazac, with a mean value of $6.1 \pm 0.3$. In contrast, the concentration of calcium ions dissolved in water showed great variations: $18.4 \pm 5.7 \mathrm{mg} / \mathrm{L}$ in the Basse Marche district, and $6.7 \pm 4.4 \mathrm{mg} / \mathrm{L}$ in the Mounts of Ambazac (Guy, 1996; Guy et al., 1996).

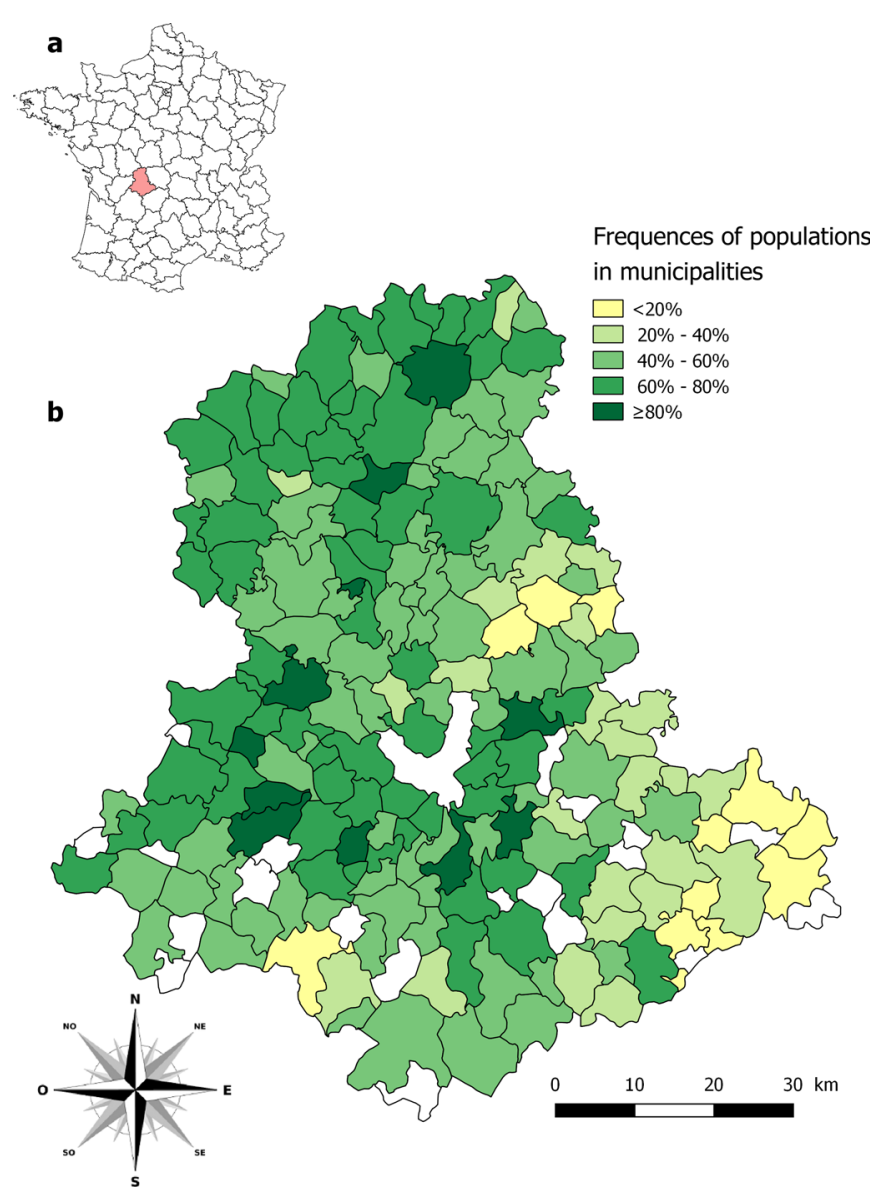

Fig. 1. Geographic location of the department of Haute Vienne in France (a) and frequency of Omphiscola glabra populations according to 179 municipalities (b).

The continental type climate is attenuated by moist winds coming from the Atlantic Ocean. However, in its eastern part, the climate undergoes a mountainous influence due to the proximity of the Massif Central (Chèvremont, 2008). The Haute Vienne is predominantly rural and the human activity is mainly focused on livestock and forestry: this department comprises 168000 ha of natural grassland and 149,996 ha of wood, which corresponds to $33.1 \%$ and $29.6 \%$ of its area, respectively.

\subsection{Snail populations}

Figure 1 shows the 179 communes on which the populations of $G$. truncatula involved in this study are located. The other 20 municipalities were excluded due to the low number of water points (see below) surveyed between 1970 and 2006.

Table 1 shows the different studies carried out by our team in the department of Haute Vienne during these 37 years and specifies the number of water points investigated. Most populations were identified between 1970 and 2006 in a total of 234 cattle- or sheep-breeding farms (Rondelaud et al., 2011). Other populations were found (i) between 1986 and 1995 in 25 other farms to study experimental transplantations of snails into new potential habitats (Vareille-Morel et al., 
Table 1. Snail investigations performed for 37 years (1970-2006) in the department of Haute Vienne with indication of their purpose and the number of water points investigated.

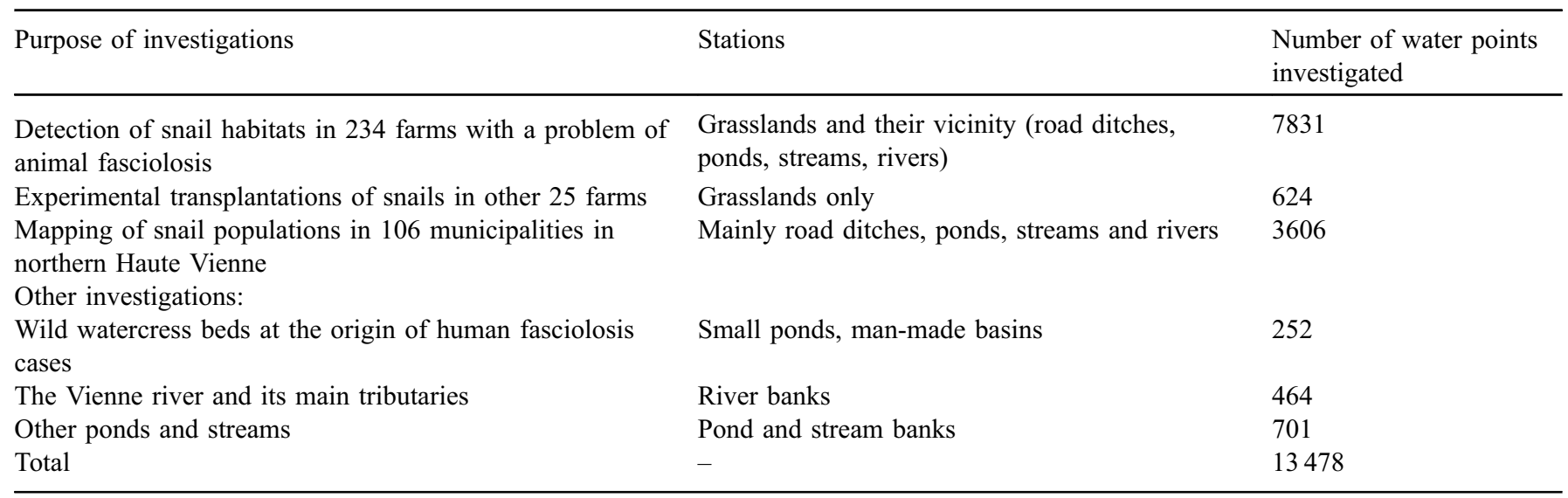

Table 2. Stations investigated from 1970 to 2006 in the department of Haute Vienne and number of positive sites for Galba truncatula.

\begin{tabular}{llll}
\hline Type of stations & Number of sites investigated & Number of sites with snails (\%) & Frequency (\%) \\
\hline Open drainage furrows & 5232 & 3986 & 76.0 \\
Springs (meadows) & 1601 & 1176 & 73.4 \\
Open drainage ditches & 1539 & 525 & 34.1 \\
Road ditches & 2174 & 1138 & 52.3 \\
Trampled areas & 279 & 20 & 7.1 \\
Pond banks & 910 & 283 & 31.0 \\
Brooks & 903 & 184 & 20.3 \\
River banks & 840 & 95 & 11.3 \\
Totals & 13478 & 7407 & 54.9 \\
\hline
\end{tabular}

2002) and (ii) between 1998 and 2000 during another study to map the distribution of $G$. truncatula in the north of the department (Rondelaud et al., 2000b). The remaining populations have been discovered in smaller studies focused on wild watercress beds, ponds, streams and rivers (Dreyfuss et al., 1997; Rondelaud et al., 2000a; Hourdin et al., 2006).

Table 2 shows the total number of these populations, taking into account the type of their habitats. Most populations were found in swampy meadows: at the peripheral end of open drainage furrows (3986), along the main drainage ditch (525), around/in temporary or permanent springs, each surrounded by a rush bed (1176) or in cattle-trampled areas (20). Another group of 1138 populations was living in road ditches when a spring head is present. The other populations were identified on pond banks (283), in permanent streams measuring less than one metre in width (184) or on river banks (95).

\subsection{Protocol of investigations}

Snail habitats have been detected in March or April using the indicator plant method (Over, 1962) because the presence of these plants points out favourable conditions under which $G$. truncatula can live (Taylor, 1965). Six species: Juncus acutiflorus (Ehrhart) ex-Hoffmann, Juncus effuses Linnaeus,
Lotus uliginosus Schkuhr, Agrostis stolonifera Linnaeus, Dactylis glomerata Linnaeus and Glyceria fluitans (Linnaeus) R. Brown, were used as indicator plants. The first three were selected because they represented more than $75 \%$ of the plant species found by Ghestem et al. (1974) or Guy et al. (1996) in the swampy meadows of northern Haute Vienne. In road ditches, the two rush species, A. stolonifera and $G$. fluitans were chosen because of their predominance in the study by Jourdin et al. (1985) in the same area. On the banks of ponds, streams and rivers, D. glomerata and G. fluitans were chosen (Dreyfuss et al., 1997; Hourdin et al., 2006). The choice of March or April for these investigations was based on the following observations: (i) all points were watered during these two months, (ii) the vegetation was sufficiently developed for the identification of Poaceae species, (iii) the populations of $G$. truncatula were only composed of adult individuals of the overwintering generation, and (iv) no predation of G. truncatula by the land snail Zonitoides nitidus O.F. Müller occurred in March-April (this only occurs in JuneJuly in grasslands on acid soils: Rondelaud, 1975; Rondelaud et al., 2006).

When an indicator plant was found near a water point, the corresponding area was studied to detect the presence of the snail. If $G$. truncatula was observed, the abundance of the population was determined by counting overwintering snails 
Table 3. Results provided by the Pearson's correlation test in the analysis of mean altitude, mean annual rainfall and mean annual temperature in the different municipalities of Haute Vienne. CI, confidence intervals.

\begin{tabular}{llll}
\hline $\begin{array}{l}\text { Pearson's correlation coefficients }(95 \% \mathrm{CI}) \\
\text { Parameters }\end{array}$ & Mean altitude & Mean annual rainfall & Mean annual temperature \\
\hline Mean altitude & 1 & $0.794(0.726 ; 0.846)^{* * *}$ & $-0.749(-0.812 ;-0.670)^{* * *}$ \\
Mean annual rainfall & $0.794(0.726 ; 0.846)^{* * *}$ & 1 & $-0.735(-0.800 ;-0.652)^{* * *}$ \\
Mean annual temperature & $-0.749(-0.812 ;-0.670)^{* * *}$ & $-0.735(-0.800 ;-0.652)^{* * *}$ & 1 \\
\hline
\end{tabular}

*** $p<0.001$.

on the area of each habitat because this generation is mainly composed of adults ( $>4 \mathrm{~mm}$ shell height) in March or April. Depending on the water level, these snails were counted at sight or after their collection using a sieve ( $3 \mathrm{~mm}$ mesh size). Habitat detection and snail counting in each meadow were carried out by two people for 30-40 min. In road ditches and along the banks, these operations were carried out by a single person for 15-20 min per habitat. The area of each habitat was then determined. Measurement of areas occupied by snails was easy for furrows, ditches, ponds, streams and rivers. Snail habitats in springs and trampled areas were mapped and their area was determined based on geometric shape and size.

The number of water points investigated when conditions are favourable for snail life was dependent on the surface area of each municipality. This number was at least 60 points for each of the 108 small municipalities $\left(<30 \mathrm{~km}^{2}\right), 90-100$ points for each of the 53 municipalities of intermediate size $\left(31-50 \mathrm{~km}^{2}\right)$ and 120 points or more for each of the 18 largest ones $\left(>50 \mathrm{~km}^{2}\right)$.

Species identification was performed on the morphology of the shell according to our experience on the lymnaeids. No molecular biology study was carried out during the period of snail investigations (1970-2006) to confirm this identification. In this study, snails present in each habitat were considered as one population.

\subsection{Geographic and climatic data}

The mean altitude of each municipality was obtained by considering that of its main city and was determined using the Carte-de-France website (http://www.cartesfrance.fr). As the mean altitude of these municipalities ranged from 160 to $570 \mathrm{~m}$, we have used four categories of altitude $(<300 \mathrm{~m}, 300-400 \mathrm{~m}$, $401-500 \mathrm{~m}$, and $>500 \mathrm{~m}$ ) to classify individual values provided by the study of several parameters. The other two variables were the mean annual rainfall and the mean annual temperature recorded in the 200 municipalities of Haute Vienne between 1971 and 2000. The latter data came from maps published by Météo France (Météo France, 2016). Five categories were used for mean annual rainfall $(<900 \mathrm{~mm}, 900-1000 \mathrm{~mm}, 1001-$ $1100 \mathrm{~mm}, 1101-1200 \mathrm{~mm}$, and $>1200 \mathrm{~mm}$ ), whereas five other categories $\left(<9.5^{\circ} \mathrm{C}, 9.5-10^{\circ} \mathrm{C}, 10.1-10.5^{\circ} \mathrm{C}, 10.6-11^{\circ} \mathrm{C}\right.$, and $>11^{\circ} \mathrm{C}$ ) were used for the mean annual temperature.

\subsection{Parameters studied}

The first was the frequency of snail habitats in each municipality and was calculated using the ratio between the number of sites with live snails and the number of water points detected by the presence of an indicator plant. The other two parameters were the surface area of each habitat and the density of overwintering snails per $\mathrm{m}^{2}$ of habitat. They were only calculated for open drainage furrows, springs and road ditches because these snail habitats are the most numerous in Haute Vienne (a total of 6300, Tab. 2). As 19 of these habitats were occupied by a mixed community with $G$. truncatula and another lymnaeid (Omphiscola glabra O.F. Müller, Stagnicola palustris O.F. Müller) or a physid (Aplexa hypnorum Linnaeus), they were excluded from this study so that habitat characteristics were only calculated for 6281 populations of $G$. truncatula.

Values for altitude, annual rainfall and annual temperature were first subjected to a Pearson's correlation test to assess the degree of relationship between these three parameters. As the latter were highly correlated with each other (Tab. 3), the frequencies given in the above categories of altitude, annual rainfall or annual temperature were subjected to a simple linear regression instead of being processed by multiple linear regression. All frequencies are given with their $95 \%$ confidence intervals. Individual values noted for the surface area of habitats and the density of overwintering snails were also classified in the different categories as above, but only for the mean altitude of municipalities. They were averaged and standard deviations were established, whatever the habitat type. Normality of these last values was analysed using Shapiro-Wilk normality test (Shapiro and Wilk, 1965). As the distributions of these values were not normal, the Kruskal-Wallis test was used to establish levels of significance. We have also used the pgirmess r package (Siegel and Castellan, 1988) as a posthoc test to do pairwise multiple comparisons. The different analyses were performed using the R 3.3.0 software ( $\mathrm{R}$ Core Team, 2016).

\section{Results}

\subsection{Frequency of snail populations}

Out of a total of 13478 water points surveyed in the 179 municipalities of Haute Vienne, the overall frequency of snail populations was $54.9 \%$ (Tab. 2). The highest frequency was noted at the peripheral extremity of open drainage furrows in grasslands $(76.0 \%)$, followed by springs $(73.4 \%)$, road ditches $(52.3 \%)$, open drainage ditches $(34.1 \%)$ and the banks of ponds $(31.0 \%)$ by decreasing order. The frequency of snail populations in each of the other four habitat types was less than $25 \%$ (Tab. 2). However, this frequency also varied with the mean altitude of municipalities, as shown in Figure 1. Values 
Table 4. Frequency of habitats occupied by Galba truncatula in the department of Haute Vienne between 1970 and 2006 in relation to different categories for the mean altitude, mean annual rainfall and mean annual temperature of municipalities.

\begin{tabular}{|c|c|c|c|}
\hline Parameter and categories & $\begin{array}{l}\text { Number of habitats with } \\
\text { Galba truncatula }\end{array}$ & $\begin{array}{l}\text { Number of water } \\
\text { points surveyed }\end{array}$ & $\begin{array}{l}\text { Frequency }(\%) \text { of snail habitats } \\
{[95 \% \text { confidence intervals }]}\end{array}$ \\
\hline \multicolumn{4}{|l|}{ Mean altitude } \\
\hline$[300 ; 400 \mathrm{~m}[$ & 2980 & 5415 & $55.03[53.60 ; 56.36]$ \\
\hline$[400 ; 500 \mathrm{~m}[$ & 598 & 2067 & $28.93[26.90 ; 30.94]$ \\
\hline$\geq 500 \mathrm{~m}$ & 108 & 784 & $13.78[11.40 ; 16.39]$ \\
\hline \multicolumn{4}{|l|}{ Mean annual rainfall } \\
\hline$<900 \mathrm{~mm}$ & 511 & 755 & $67.68[64.20 ; 71.01]$ \\
\hline$[900 ; 1000 \mathrm{~mm}[$ & 3166 & 4815 & $65.75[64.30 ; 67.09]$ \\
\hline$[1000 ; 1100 \mathrm{~mm}[$ & 2371 & 4395 & $53.95[52.40 ; 55.43]$ \\
\hline$[1100 ; 1200 \mathrm{~mm}[$ & 1172 & 2884 & $40.64[38.80 ; 42.46]$ \\
\hline$\geq 1200 \mathrm{~mm}$ & 187 & 629 & $29.73[26.10 ; 33.47]$ \\
\hline \multicolumn{4}{|l|}{ Mean annual temperature } \\
\hline$\left[10^{\circ} \mathrm{C} ; 10.5^{\circ} \mathrm{C}[\right.$ & 563 & 1734 & $32.47[30.20 ; 34.73]$ \\
\hline$\left[10.5^{\circ} \mathrm{C} ; 11^{\circ} \mathrm{C}[\right.$ & 2861 & 5479 & $52.22[50.80 ; 53.55]$ \\
\hline$\geq 11^{\circ} \mathrm{C}$ & 3916 & 5850 & $66.94[65.70 ; 68.15]$ \\
\hline Total & 7407 & 13478 & $54.96[54.10 ; 55.80]$ \\
\hline
\end{tabular}

Table 5. Values provided by a simple linear regression when used to calculate the relationship between the frequency of habitats with Galba truncatula and the mean altitude, mean annual rainfall or mean annual temperature in different municipalities of Haute Vienne. Abbreviation: df, degrees of freedom.

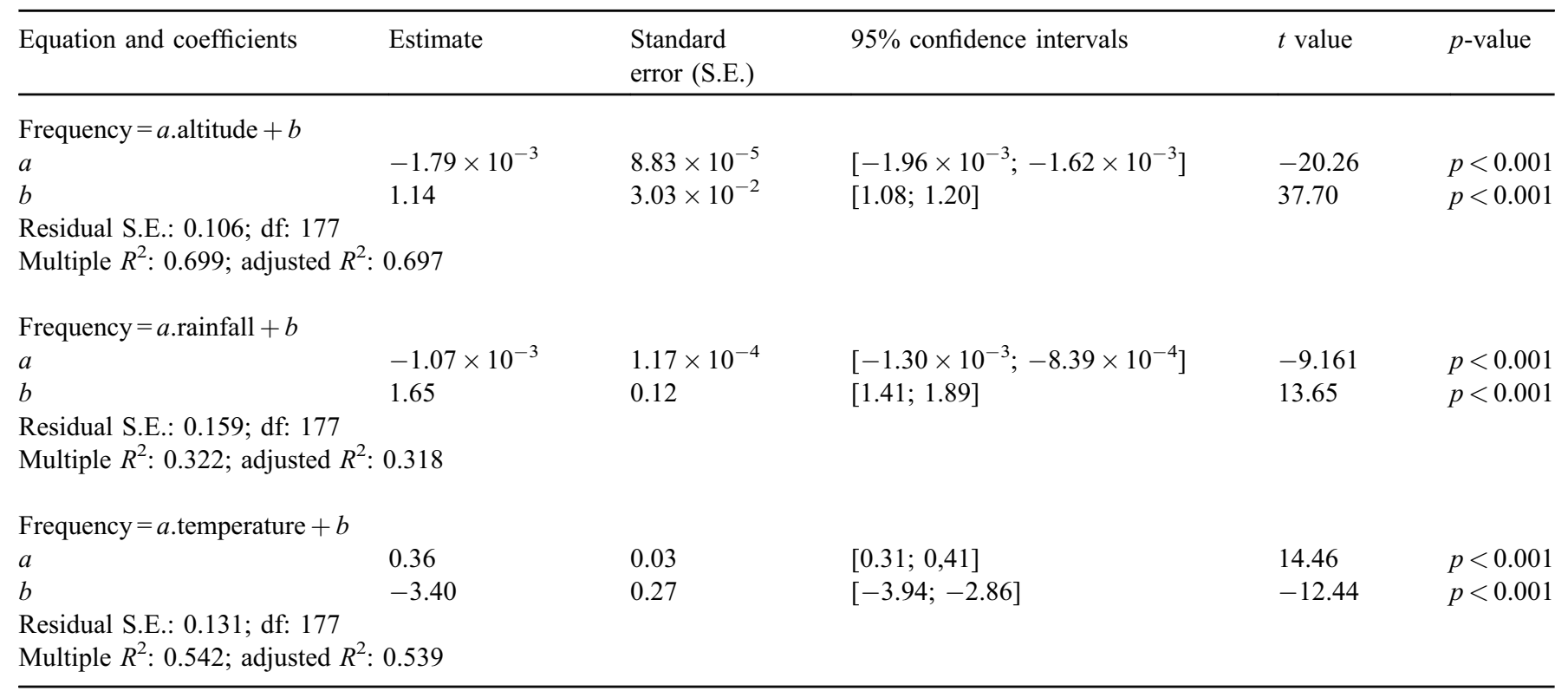

above $80 \%$ were recorded in only 11 municipalities in the west and north of this department. In contrast, the lowest values $(<20 \%)$ were noted for the municipalities (in pale yellow) located in the Mounts of Limousin located along the eastern, south-eastern and south-western borders of the department. Table 4 shows this decrease in frequencies with the increase in altitude: from $71.3 \%$ in municipalities under $300 \mathrm{~m}$ to $13.7 \%$ in those above $500 \mathrm{~m}$ altitude. This decrease was significantly correlated $(p<0.001)$ with the increasing altitude of municipalities, as shown in Table 5 (linear regression). This model can explain $69.7 \%$ of total variance in the frequency of snail populations. 


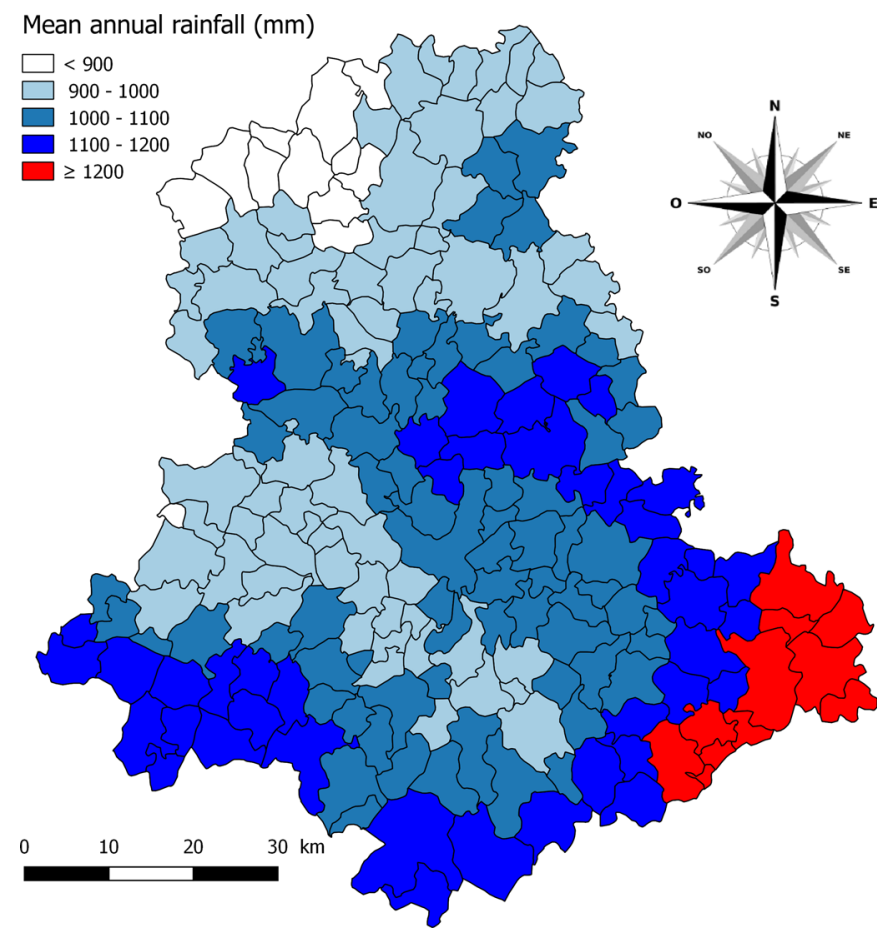

Fig. 2. Mean annual rainfall from 1971 to 2000 in the 200 municipalities of the Haute Vienne department.

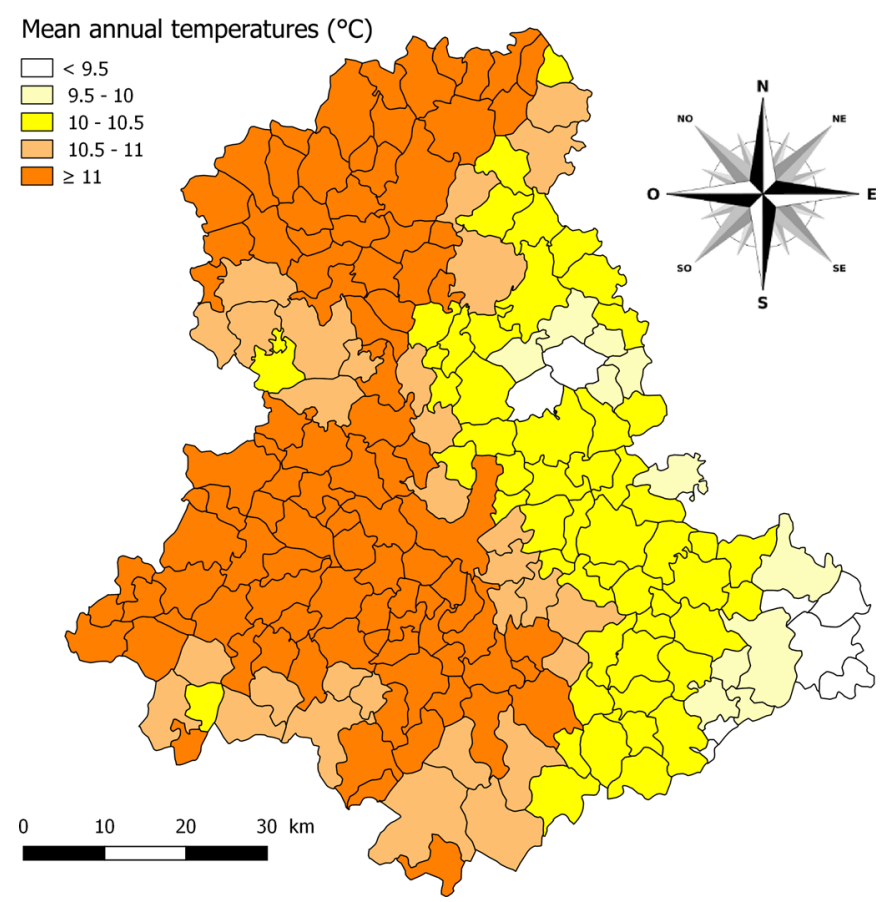

Fig. 3. Mean annual temperature from 1971 to 2000 in the 200 municipalities of the Haute Vienne department.

Figure 2 shows variations in mean annual rainfall in the 200 municipalities of Haute Vienne. Annual rainfall was closely related to the mean altitude of the communes (Tab. 3). The lowest precipitations were noted in the communes at the northern limit of Haute Vienne and these values increased in

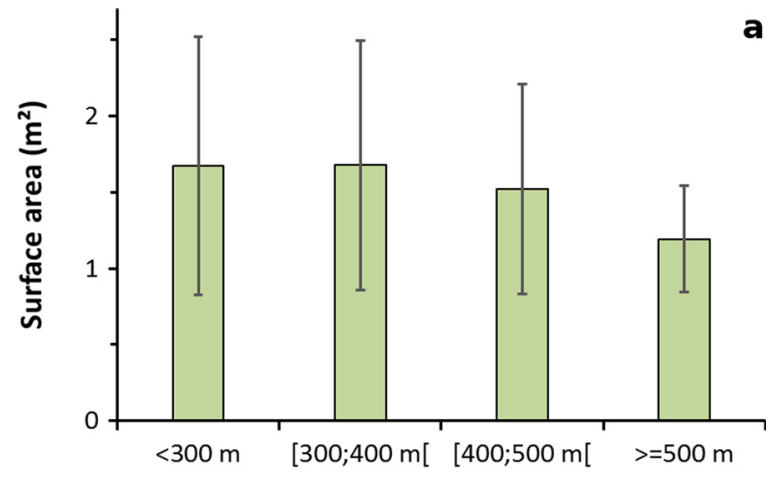

Altitude classes

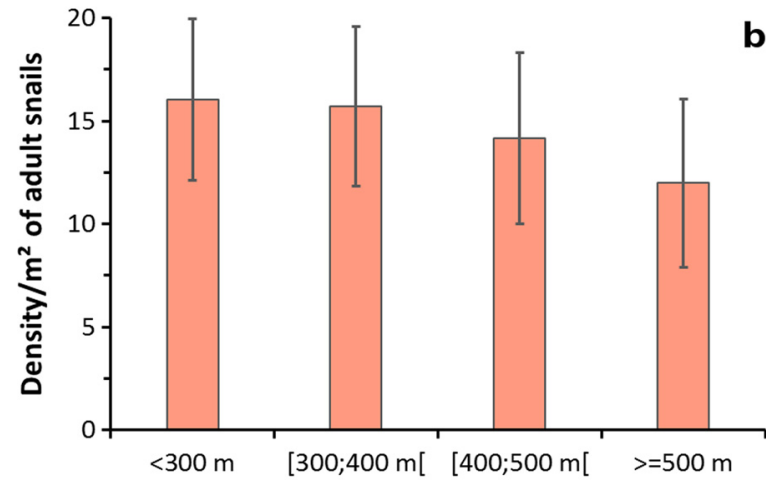

Altitude classes

Fig. 4. Surface area of habitats (a) and density. $\mathrm{m}^{-2}$ of overwintering snails (b) for 6281 populations of Galba truncatula identified between 1970 and 2006 in the department of Haute Vienne. These mean values and their SDs are presented for four altitude categories.

intensity towards the south of the department. The most abundant precipitations $(>1200 \mathrm{~mm}$ per year) were noted in the communes on the eastern, south-eastern and south-western borders of the department where the Limousin Mounts are located. A significant relationship $(p<0.001)$ between the decrease in the frequencies of snail populations and the increase in mean annual precipitations was noted, as shown in Tables 4 and 5. However, this model based on the annual precipitations can only explain $31.8 \%$ of total variance in the frequencies (Tab. 4). On the other hand, the mean annual temperature (Fig. 3) has an inverse distribution in the department, with the highest values in the municipalities located in the north and west, while the lower ones are on the eastern and south-eastern borders. There was also a positive and significant $(p<0.001)$ relationship between the increase in frequencies and that of the mean annual temperature in municipalities (Tabs. 4 and 5). The latter model explains $53.9 \%$ of total variance in the frequencies (Tab. 5).

\subsection{Characteristics of snail habitats}

As altitude was the best factor to explain total variance in the frequency of snail populations, it was chosen to analyse potential changes in habitat area or the density of overwintering snails in relation to the relief of Haute Vienne. Figure 4 shows the mean values of the two parameters and their 
standard deviations in relation to the four altitude categories. The surface area of $G$. truncatula habitats decreased significantly $\left(H_{3}=52.59, p<0.001\right)$ with the increase in altitude, ranging from $1.67 \mathrm{~m}^{2}$ in municipalities under $300 \mathrm{~m}$ to $1.19 \mathrm{~m}^{2}$ in those above $500 \mathrm{~m}$ (Fig. 4a). Apart from the difference between the mean values recorded in the $<300 \mathrm{~m}$ and $300-400 \mathrm{~m}$ categories, the differences between the other categories were all significant. Similarly, the density of overwintering snails per $\mathrm{m}^{2}$ of habitat decreased significantly $\left(H_{3}=166.85, p<0.001\right)$ with the increase in altitude, ranging from $16.0 . \mathrm{m}^{-2}$ in municipalities under $300 \mathrm{~m}$ to $11.9 . \mathrm{m}^{-2}$ in those above $500 \mathrm{~m}$ (Fig. 4b). Pairwise comparison of mean densities revealed that all differences were significant.

\section{Discussion}

The results reported in the present study were mainly compared with those that Vareille-Morel et al. (2007) and Rondelaud et al. (2011) provided during their investigations in a total of 361 farms raising cattle or sheep on the acid soils of northern Corrèze, Creuse and Haute Vienne. The percentages reported in our study for the habitats with $G$. truncatula in open drainage furrows, springs and trampled areas are lower than those provided by Rondelaud et al. in 2011: 76.0\%, 73.4\% and $7.1 \%$ of water points investigated (Tab. 2), respectively, instead of $84.1 \%, 81.4 \%$ and $14.8 \%$ (out of 5546, 1454 and 233 water points for Rondelaud et al. in 2011). Conversely, the habitats located on the banks of watercourses (streams + rivers) are higher in our study (a total of $31.6 \%$ : Tab. 2 , instead of $22.4 \%$ ), while the percentages of snail habitats in open drainage ditches, road ditches and pond banks are close to each other. These variations in percentages must be reported to the stations studied because Rondelaud et al. (2011) carried out their investigations only in the meadows of 361 farms and their immediate vicinity, while our study focused on a higher number of water points located in 179 communes of Haute Vienne. These results demonstrate that swampy grasslands with their open drainage networks, springs and trampled areas were the best sites for the development of $G$. truncatula populations on the acid soils of Limousin: $81.6 \%$ of the 7709 habitats identified by Vareille-Morel et al. (2007) in this region. On the other hand, the banks of the main rivers constitute unfavourable habitats for this species, especially in the sections located to the east of the department (Dreyfuss et al., 1997).

On the acid soils of Haute Vienne, the frequency of $G$. truncatula populations significantly decreased when the mean altitude of municipalities increased: from $71.3 \%$ in municipalities under $300 \mathrm{~m}$ to $13.7 \%$ in those above $500 \mathrm{~m}$ (Tab. 4). This decrease in frequencies was also noted when the mean annual rainfall increased or when the mean annual temperature decreased. This result is rather difficult to interpret due to a relative lack of information on this point in the literature. In South Africa, De Kock et al. (2003) reported results similar to ours by examining the distribution of $723 \mathrm{G}$. truncatula populations in relation to altitude, mean annual rainfall and mean annual temperature of habitats. According to these authors, temperature was an important determinant in the geographical distribution of the species, while altitude only had a limited role due to the diversity of landscapes and climatic conditions (De Kock et al., 2003). The decrease in the number of populations noted in the present study above $500 \mathrm{~m}$ altitude may be due to the effect of temperature alone on the development of $G$. truncatula, as a minimum temperature of $10{ }^{\circ} \mathrm{C}$ is required for the growth of the snail (Kendall, 1953; 1965). Two arguments support this approach: (i) the existence of a single annual generation for $G$. truncatula (instead of two per year usually in lowlands) in the department of Creuse, near Haute Vienne, above $500 \mathrm{~m}$ (Rondelaud and Mage, 1992) or in the French Jura and Alps when altitude rises (De Massias et al., 1996); (ii) the slower development of $F$. hepatica larval forms in $G$. truncatula in the alpine regions of Switzerland: up to two years for Eckert et al. (2005). But the foregoing explanation is far from satisfactory and another factor must be sought to explain this decrease in G. truncatula populations in Haute Vienne above $500 \mathrm{~m}$ altitude. In fact, the snail has already been observed at higher altitudes in Western Europe: up to $1200 \mathrm{~m}$ in the French Jura (De Massias et al., 1996), $2100 \mathrm{~m}$ in Switzerland (Eckert et al., 1975) and $2600 \mathrm{~m}$ in the French Alps (De Massias et al., 1996) and the Pyrenees (Combes, 1968). Under these conditions, it is necessary to assume the existence of specific ecological conditions for $G$. truncatula in the municipalities of Haute Vienne. One of these factors could be the abundance of peat bogs found above $500 \mathrm{~m}$ altitude in the Limousin region: 2359 in the Corrèze, Creuse and Haute Vienne departments, sometimes extending over 12 hectares or more (Conservatoire d'Espaces Naturels du Limousin, 2012). According to Allée et al. (1997), this high frequency of peat bogs on these acid soils would be linked to the disappearance of many forests in the Limousin watersheds over the centuries and, consequently, to water accumulation in these areas due to changes in water circulation. However, another explanation based on the predominance of conifers in areas above $500 \mathrm{~m}$ altitude and the effect of their needles on the acidification of runoff (Hornung, 1985) cannot be completely excluded.

The characteristics of $G$. truncatula habitats located in open drainage furrows, springs and road ditches significantly decreased with increasing altitude of municipalities. In those under $300 \mathrm{~m}$, the mean surface area of snail habitats was $1.67 \mathrm{~m}^{2}$ and gradually decreased up to $1.19 \mathrm{~m}^{2}$ in municipalities above $500 \mathrm{~m}$ (Fig. 4a). This result must be related to the type of habitat found in the municipalities studied according to altitude. Habitats in road ditches were numerous under $400 \mathrm{~m}$ altitude. Their number sharply decreased between 400 and $500 \mathrm{~m}$ altitude to be very low above $500 \mathrm{~m}$. As the habitats located in these ditches may have an area exceeding $5 \mathrm{~m}^{2}$ on the acid soils of Limousin (Rondelaud et al., 2011), the decrease in their number from $400 \mathrm{~m}$ altitude may explain the smaller areas that we noted between 400 and $570 \mathrm{~m}$. The decrease in the density of overwintering snails per $\mathrm{m}^{2}$ of habitat can partly be explained by the winter conditions, which are more severe in municipalities above $500 \mathrm{~m}$ altitude than in those with lower altitude, which would have a negative effect on the survival of overwintering snails. Another assumption is that the lower density of overwintering snails noted above $500 \mathrm{~m}$ altitude would be due to more acid soils. This latter hypothesis is supported by the low $\mathrm{pH}$ values in running water (pH 5.4-5.6) noted in several habitats of G. truncatula in the Mounts of Ambazac and those of Limousin (Rondelaud, personal observation). 
In conclusion, the distribution of G. truncatula populations on the acid soils of Haute Vienne is closely related to the relief and climatic conditions of municipalities. Their number showed a gradual decrease when the mean altitude and mean annual rainfall of municipalities are increasing, or when the mean annual temperature is decreasing. The characteristics of snail habitats also showed the same decrease with the increase in altitude. Further observations are needed to confirm these results in other French regions or other temperate countries on acid soils.

Acknowledgements. The authors gratefully thank M. Abrous, D. Bouix-Busson, B. Didier and C. Vareille-Morel for providing their data on the snail populations they have investigated in the Haute Vienne department during their studies. They are also grateful to several PharmD students: C. Apostoloff, L. Farge, C. Granet, D. Guichard, F. Guy, C. Lacourarie, S. Nauche, L. Vareille and F. Xuereb, for their assistance in the field.

\section{References}

Allée P, Diot MF, Durieux JF, Reynet JM, Valadas B. 1997. Trois mille ans d'enregistrement sédimentaire dans les fonds de vallons des bas-plateaux limousins. In: La dynamique des paysages protohistoriques antiques, médiévaux et modernes. Actes des XVII èmes Rencontres Internationales d'Archéologie et d'Histoire d'Antibes, Sophia-Antipolis, 19-21 octobre 1996, pp. 365-387.

Baggenstos R, Dahinden T, Torgerson PR, Bär H, Rapsch C, Knubben-Schweizer G. 2016. Validation of an interactive map assessing the potential spread of Galba truncatula as intermediate host of Fasciola hepatica in Switzerland. Geospat. Health 11: 137143.

Bargues MD, Gayo V, Sanchis J, Artigas P, Khoubbane M, Birriel S, Mas-Coma S. 2017. DNA multigene characterization of Fasciola hepatica and Lymnaea neotropica and its fascioliasis transmission capacity in Uruguay, with historical correlation, human report review and infection risk analysis. PLOS Negl. Trop. Dis. 11: e0005352.

Chèvremont P. 2008. Carte géologique harmonisée du département de la Haute-Vienne (87). Notice technique. Orléans (France): BRGM/ RP-57447-FR, 236 p.

Combes C. 1968. Biologie, écologie des cycles et biogéographie de Digènes et Monogènes d'Amphibiens dans les Pyrénées. Mém. Mus. Natl Hist. Nat., Sér. A - Zool. 51, 1-195.

Conservatoire d'Espaces Naturels du Limousin. 2012. Le patrimoine naturel préservé par le Conservatoire d'Espaces Naturels du Limousin. Bilan de 20 ans d'actions : 1992-2012, Conservatoire d'Espaces Naturels du Limousin, Saint Gence, France, 156 p.

De Kock KN, Wolmarans CT, Bornman M. 2003. Distribution and habitats of the snail Lymnaea truncatula, intermediate host of the liver fluke Fasciola hepatica, in South Africa. J South Afr Vet Assoc 74: 117-122.

De Massias E, Rondelaud D, Mage C, Gevrey J. 1996. Lymnaea truncatula Müller dans les zones de haute altitude. Existence d'une seule génération annuelle. Bull Soc Fr Parasitol 14: 54-61.

Dreyfuss G, Vareille-Morel C, Rondelaud D. 1997. Les habitats de Lymnaea truncatula Müller (Mollusque) le long de deux rivières. Ann Limnol-Int J Limnol 33: 67-72.

Dreyfuss G, Vignoles P, Rondelaud D, Cabaret J. 2015. The mud snail (Galba truncatula). Ecology, parasitism and control. Saarbrücken (Germany): Lambert Academic Publishing, 238 p.
Eckert J, Sauerländer R, Wolff K. 1975. Haüfigkeit und geographische Verbreitung von Fasciola hepatica in der Schweiz. Schweiz Arch Tierheilkd 117: 173-184.

Eckert J, Friedhoff KT, Zahner H, Deplazes P. 2005. Lehrbuch der Parasitologie für die Tiermedizin. Stuttgart. Germany: Enke Verlag, $575 \mathrm{p}$.

Fox NJ, White PCL, McClean CJ, Marion G, Evans A, Hutchings MR. 2011. Predicting impacts of climate change on Fasciola hepatica risk. Plos One 6: e16126.

Ghestem A, Morel-Vareille C, Rondelaud D, Vilks A. 1974. Premiers documents phytosociologiques des biotopes à Lymnaea (Galba) truncatula Müller (Mollusque Gastéropode) dans le nord-ouest du Limousin. Bull Soc Hist Nat Toulouse 110: 235-240.

Granai S, Limondin-Lozouet N, Chaussé C. 2011. Evolution paléoenvironnementale de la vallée de la Seine au tardiglaciaire et à l'holocène, à Paris (France) d'après l'étude des malacofaunes. Quaternaire 22: 327-344.

Guitter F, Andrieu-Ponel V, De Beaulieu JL, Cheddadi R, Calvez M, Ponel P, Reille M, Keller T, Goeury C. 2003. The last climatic cycles in western Europe: a comparison between long continuous lacustrine sequences from France and other terrestrial records. Quat Int 111: 59-74.

Guy F. 1996. Étude de relations entre la végétation et le mollusque Lymnaea truncatula Müller dans les jonchaies prairiales de la Haute-Vienne. PharmD thesis, University of Limoges, $103 \mathrm{p}$.

Guy F, Rondelaud D, Botineau M, Dreyfuss G, Ghestem A. 1996. Etude de relations entre les plantes les plus fréquentes et l'abondance de Lymnaea truncatula Müller, vecteur de Fasciola hepatica Linné dans les prairies marécageuses sur sol acide. Revue Méd Vét 147: 465-470.

Hornung M. 1985. Acidification of soils by trees and forests. Soil Use Manag 1: 24-28.

Hourdin P, Vignoles P, Dreyfuss G, Rondelaud D. 2006. Galba truncatula (Gastropoda, Lymnaeidae): effects of daily water-level variations on the ecology and ethology of populations living upstream of a dam. Ann Limnol - Int J Lim. 42: 173-180.

Jourdin S, Rondelaud D, Descubes-Gouilly C, Ghestem A. 1985. La distribution des Mollusques Pulmonés dans une prairie marécageuse est-elle dépendante de celle des groupe-ments végétaux constitutifs? Bull Soc Hist Nat Toulouse 121: 107-114.

Kendall SB. 1953. The life-history of Limnaea truncatula under laboratory conditions. J Helminthol 27: 17-28.

Kendall SB. 1965. Relationships between the species of Fasciola and their molluscan hosts. Adv Parasitol 3: 59-98.

Limondin N, Rousseau DD. 1991. Holocene climate as reflected by a malacological sequence at Verrieres, France. Boreas 20: 207-229.

Magnin F, Bonnet S. 2014. Une succession malacologique du pléniglaciaire moyen et du postglaciaire à Aix-en-Provence (France): éléments de datation, taphonomie des assemblages et paléoenvironnements. Quaternaire 25: 163-185.

Malone JB, Yilma JM. 1999. Predicting outbreaks of fasciolosis: from Ollerenshaw to satellites. In: Dalton JP, ed. Fasciolosis. Wallingford, Oxon (UK): CABI Publishing, pp. 151-183.

Malone JB, Gommes R, Hansen J, Yilma JM, Slingenberg J, Snijders F, Nachtergaele F, Ataman E. 1998. A geographic information system on the potential distribution of Fasciola hepatica and F. gigantica in East Africa based of food and agriculture organization database. Vet Parasitol 78: 87-101.

Malone JB, Bergquist NR, Huh OK, Bavia ME, Bernardi M, El Bahy MM, Fuentes MV, Kristensen TK, McCarroll JC, Yilma JM, Zhou XN. 2001. A global network for the control of snail-borne disease using satellite surveillance and geographic information systems. Acta Trop 79: 7-12. 
Mas-Coma S, Valero MA, Bargues M.D. 2009. Fasciola, lymnaeids and human fascioliasis, with a global overview on disease transmission, epidemiology, evolutionary genetics, molecular epidemiology and control. Adv Parasitol 69: 41-146.

Météo France. 2016. Météo France: actualités sur la météo et le climat, dossiers, infographies, vidéos. http://www.meteofrance.fr/ (accessed on 16 December 2016).

Muséum National d'Histoire Naturelle. 2003-2017. Inventaire national du patrimoine naturel. Cas de Galba truncatula. https:// inpn.mnhn.fr/espece/cd_nom/64043 (accessed on 16 October 2017).

Novobilský A, Novák J, Björkman C, Höglund J. 2015. Impact of meteorological and environmental factors on the spatial distribution of Fasciola hepatica in beef cattle herds in Sweden. BMC Vet Res 11: 128.

Ollerenshaw CB. 1971. Some observations on the epidemiology of fascioliasis in relation to the timing of molluscicide applications in the control of the disease. Vet Rec 88: 152-164.

Ollerenshaw CB, Smith LP. 1969. Meteorological factors and forecast of helminthic diseases. Adv Parasitol 7: 283-323.

Over H.J., 1962. A method of determining the liver fluke environment by means of the vegetation type. Bull Off Int Epiz 58: 297-304.

Rapsch C, Dahinden T, Heinzmann D, Torgerson PR, Braun U, Deplazes P, Hurni L, Bär H, Knubben-Schweizer G. 2008. An interactive map to assess the potential spread of Lymnaea truncatula and the free-living stages of Fasciola hepatica in Switzerland. Vet Parasitol 154: 242-249.

R Core Team. 2016. R: a language and environment for statistical computing. Vienna: R Foundation for Statistical Computing. https://www.R-project.org (accessed on 27 May 2016).

Rondelaud D. 1975. La prédation de Lymnaea (Galba) truncatula Müller par Zonitoides nitidus Müller, moyen de lutte biologique. Ann Parasitol Hum Comp 50: 55-61.

Rondelaud D, Mage C. 1992. Lymnaea truncatula Müller: les conséquences d'une seule génération annuelle sur les caractéristiques de l'infestation par Fasciola hepatica L. Revue Méd Vét 143: 843-846.

Rondelaud D, Dreyfuss G, Bouteille B, Dardé ML. 2000a. Changes in human fasciolosis in a temperate area. About some observations over a 28-year period in central France. Parasitol Res 86: 753-757.

Rondelaud D, Vignoles P, Dreyfuss G, Vareille-Morel C, Xuereb F, Apostoloff C. 2000b. Cartographie de la répartition des Mollusques Lymnaeidae et d'espèces voisines dans la Basse-Marche (secteur nord de la Haute-Vienne). Ann Sci Limousin 11: 1-18.
Rondelaud D, Vignoles P, Dreyfuss G, Mage C. 2006. The control of Galba truncatula (Gastropoda: Lymnaeidae) by the terrestrial snail Zonitoides nitidus on acid soils. Biol Control 39: 290-299.

Rondelaud D, Hourdin P, Vignoles P, Dreyfuss G, Cabaret J. 2011. The detection of snail host habitats in liver fluke infected farms by use of plant indicators. Vet Parasitol 181: 166-173.

Seddon MB, Kebapçı U, Van Damme D. 2015. Galba truncatula. The IUCN Red List of Threatened Species 2015: e. T155730A85693575. http://dx.doi.org/10.2305/IUCN.UK.2015. RLTS.T155730A85693575.en. (accessed on 15 October 2017).

Selemetas N, Ducheyme E, Phelan P, O'Kiely P, Hendrickx G, de Waal T. 2015. Spatial analysis and risk mapping of Fasciola hepatica infection in dairy herds in Ireland. Geospat Health 9: $281-$ 291.

Shapiro SS, Wilk MB. 1965. An analysis of variance test for normality (complete samples). Biometrika 52: 591-611.

Siegel S, Castellan NJ. 1988. Nonparametric statistics for the behavioral sciences. New York (USA): MacGraw Hill Int., 399 p.

Taylor EL. 1965. Fascioliasis and the liver-fluke. FAO Agricultural Studies. Roma, Italy, no. 64, 235 p.

Torgerson P, Claxton J. 1999. Epidemiology and control. In: Dalton JP, ed. Fasciolosis. Oxon(UK): CABI Publishing, pp. 113-149.

Tum S, Puotinen ML, Skerratt LF, Chan B, Sothoeun S. 2007. Validation of a geographic information system model for mapping the risk of fasciolosis in cattle and buffaloes in Cambodia. Vet Parasitol 143: 364-367.

Vareille-Morel C, Dreyfuss G, Rondelaud D. 1999. The characteristics of habitats colonized by three species of Lymnaea in swampy meadows on acid soil: their interest for fasciolosis control. Ann Limnol - Int J Lim. 35: 173-178.

Vareille-Morel C, Rondelaud D, Dreyfuss G. 2002. Experimental colonization of new habitats by Galba truncatula O.F. Müller (Gastropoda: Lymnaeidae) in central France and their susceptibility to experimental infection with Fasciola hepatica. Ann Limnol - Int J Lim. 38: 35-40.

Vareille-Morel C, Dreyfuss G, Rondelaud D. 2007. Les habitats des Lymnaeidae sur sol acide. A propos de quelques observations dans la région Limousin sur une trentaine d'années. MalaCo 4: 143-147.

Vignoles P, Rondelaud D, Dreyfuss G. 2017. Determination of zones at risk for fasciolosis in the department of Haute Vienne (France): a retrospective study on natural infections detected in 108481 Galba truncatula for 37 years. Parasite 24: 55.

Cite this article as: Dreyfuss G, Vignoles P, Rondelaud D. 2018. Relationships between the distribution of Galba truncatula (Gastropoda: Lymnaeidae) climatic conditions and the altitude of municipalities in Haute Vienne (France). Ann. Limnol. - Int. J. Lim. 54: 19 